\title{
Identification of a novel glycoprotein-binding activity in Streptococcus pyogenes regulated by the mga gene
}

\author{
Jukka Hytönen, Sauli Haataja, Pia Isomäki† and Jukka Finne \\ Author for correspondence: Jukka Hytönen. Tel: +358 2333 7445. Fax: +35823337229. \\ e-mail: jukka.hytonen@utu.fi
}

Department of Medical Biochemistry, University of Turku, Kiinamyllynkatu 10, FIN-20520 Turku, Finland

\begin{abstract}
The interaction between Streptococcus pyogenes and the host cell surface is not completely understood. Characterization of the adhesion mechanisms of the bacterium to the host cell surface is needed in order to develop new vaccines and anti-adhesion drugs. The presence of glycoprotein-binding activities among streptococcal strains was investigated. An activity binding to thyroglobulin, fetuin, asialofetuin and mucin but not non-glycosylated proteins was found to be present in the majority of the $S$. pyogenes strains studied. Cross-inhibition experiments suggested that the glycoproteins share a common structure recognized by the bacteria. The glycoprotein-binding activity was found to be proteinaceous, tightly attached to the bacterial surface and it also mediated the adherence of bacteria to solid surfaces coated with glycoproteins. The activity was found by transposon mutagenesis and complementation to be regulated by the multiple-gene regulator Mga, which has been implicated as a regulator of $S$. pyogenes virulence factors.
\end{abstract}

Keywords: Streptococcus pyogenes, bacterial adhesion, transposon mutagenesis, glycoproteins

\section{INTRODUCTION}

Streptococcus pyogenes is an important human pathogen causing a wide variety of infections ranging from tonsillitis, impetigo and erysipelas to severe life threatening infections like necrotizing fasciitis and sepsis, which have increased in number during the last few years (Chelsom et al., 1994). This drives us to look for new preventive methods and therapies. Characterization of the molecular basis of interactions between $S$. pyogenes and the host could provide us with new candidate vaccines. Furthermore, novel anti-adhesive drugs could be developed using analogues of receptor molecules to prevent the bacteria from binding to host cells (Karlsson, 1995; Beuth et al., 1996; Zopf et al., 1996; Zopf \& Roth, 1996).

The adherence of bacteria to host cells is in many cases mediated by lectin-like adhesins on the bacterial surface binding to carbohydrate receptors (Beachey, 1981; Ofek

† Present address: Kennedy Institute of Rheumatology, Hammersmith, London W6 8LH, UK.

Abbreviations: $\mathrm{ECL}$, enhanced chemiluminescence; HRP, horse radish peroxidase; THY, Todd-Hewitt medium containing $0.5 \%$ yeast extract.
\& Sharon, 1990), which are present on the host cell surface as part of the membrane glycoproteins and glycolipids. Escherichia coli is known to bind at least to eight different carbohydrate structures via its surface proteins (Karlsson, 1995; Sharon, 1996; Sharon \& Lis, 1997). Some of the carbohydrate structures have been used to inhibit the binding of Esc. coli to the host intestinal epithelia (Mouricout et al., 1990). Likewise, streptococcal infections of the human pharyngeal epithelia, where local administration of the drug to the infection focus would be easy to carry out, would be a suitable target for anti-adhesive therapy. Unfortunately, very little is known about the streptococcal receptors on host cells.

A number of $S$. pyogenes surface proteins interacting with the human host have been identified. Some of these, like the fibronectin-binding proteins (Talay et al., 1991, 1992; Courtney et al., 1992, 1994; Hanski \& Caparon, 1992; Kreikemeyer et al., 1995; Rakonjac et al., 1995; Jaffe et al., 1996; Rocha \& Fischetti, 1999), are adhesins, while others, for example M-like proteins (Cleary \& Retnoningrum, 1994) and C5a peptidase (Chen \& Cleary, 1990), are protective against the host immunodefence system. M-protein has a dual role, 
being the major antiphagocytic factor of $S$. pyogenes and also an adhesin that binds fibronectin, fibrinogen and albumin, among others (Fischetti et al., 1988; Schmidt et al., 1993; Gubbe et al., 1997). The ability of $S$. pyogenes to infect and to persist in varied locations of the human host is in part controlled by the multiple-gene regulator of S. pyogenes, Mga, which controls the expression of the M-protein (emm), M-like proteins ( $f r A$, enn, sph) and C5a peptidase (scpA) genes (Podbielski et al., 1996a). These genes are located in one regulon where the transcription of the genes downstream of the $m g a$ gene is monocistronically regulated. The genes encoding the opacity factor (sof), secreted inhibitor of the complement cascade (sic) and streptococcal cysteine protease $(s p e B)$ are also regulated by Mga (Podbielski et al., 1996a).

The purpose of the present study was to characterize glycoprotein-binding specificities of streptococci to understand the interaction between the bacteria and the potential carbohydrate receptor structures of the host cell surface. A glycoprotein-binding adhesion activity was shown to be present in the majority of the $S$. pyogenes strains studied. Using transposon mutagenesis, the novel glycoprotein-binding activity was shown to be regulated by Mga.

\section{METHODS}

Bacterial strains and culture conditions. Streptococcus pyogenes clinical isolate A8173 (type M2) and group D streptococci (D1213, D1263, D1448, D1470, D7637, D7883) were provided by K. Kunnas, National Department of Health, Kuopio, Finland. S. pyogenes (Tyks 2/8-114, Tyks3/7-150, Kuo 36/5623, OHI R5/65G and SAN R67/32), group C (Cstrept 5/95, C-strept 13/95, C-strept 21/95, C-strept 120/95, C-strept 164/95 and C-strept 200/95) and group G streptococci (G-strep 1/95, G-strep 37/95, G-strep 59/95, G-strep 5/95, G-strep 38/95 and G-strep 74/95) were isolated from throat, wound or blood and were provided by P. Huovinen, National Department of Health, Turku, Finland (Kataja et al., 1998a, b). S. pyogenes M2 71-676 wild-type and mutant strains (Podbielski et al., 1996b; Schmidt et al., 1997) were kindly provided by A. Podbielski, University Hospital Ulm, Ulm, Germany and S. pyogenes CS101 and mutant strains by $\mathrm{M}$. Boyle, Medical College of Ohio, Toledo, USA (Podbielski et al., 1996b). Escherichia coli JM109 was obtained from Promega.

Streptococcal strains and Enterococcus faecalis were grown on Todd-Hewitt (Difco) plates or media supplemented with $0.5 \%$ yeast extract (THY; Biokar Diagnostics). Esc. coli was grown in Luria broth. All cultures were incubated at $37^{\circ} \mathrm{C}$ in ambient air unless otherwise stated. All bacteria were stored at $-70{ }^{\circ} \mathrm{C}$ in growth medium containing $15 \%(\mathrm{v} / \mathrm{v})$ glycerol. The M2 71-676 and CS101 pSF152 mutants were grown in the presence of $60 \mu \mathrm{g}$ spectinomycin $\mathrm{ml}^{-1}$. Recombinant Esc. coli JM109 was grown with $60 \mu \mathrm{g}$ carbenicillin $\mathrm{ml}^{-1}$.

Materials. Bovine and porcine thyroglobulin, bovine fetuin and asialofetuin, bovine submaxillar mucin, horse myoglobin, bovine erythrocyte carbonic anhydrase, BSA, trypsin, chickenegg-white trypsin inhibitor, streptavidin-HRP (horse radish peroxidase), diaminobenzidine, lysozyme, spectinomycin, streptomycin, tetracycline and carbenicillin were purchased from Sigma. Human thyroglobulin was from Biogenesis and human fibronectin from Chemicon. NHS-LC biotin was obtained from Pierce and the biotinylated derivatives were prepared according to the instructions of the manufacturer. Nitrocellulose membrane $(0 \cdot 45 \mu \mathrm{m})$ was from Schleicher \& Schuell. Tween 20 and PEG (20000) were from Fluka. ECL Western blotting kit, Hybond-N + membrane, Sequenase 2.0 sequencing kit, $\left[\gamma^{32} \mathrm{P}\right] \mathrm{ATP},\left[\alpha-{ }^{32} \mathrm{P}\right] \mathrm{dCTP}$ and $\left[\alpha^{35} \mathrm{~S}\right] \mathrm{dATP}$ were obtained from Amersham. Sephadex G-25 and Sephadex G-50 were purchased from Pharmacia Biotech. Tran ${ }^{35}$ S-label was from ICN Biomedicals and Microbeta plates from Wallac. Hyperfilm ECL (Amersham) was used in ECL autoradiography. Sequencing gels were visualized on Fuji RX medical X-ray film. All molecular biology reagents were obtained from Promega.

Glycoprotein-binding assay. Bacteria grown overnight on THY plates were collected and washed twice by centrifugation in PBS and adjusted to a concentration that gave an $\mathrm{OD}_{600}$ of 0.5 with a Beckman DU 640 spectrophotometer and $1 \mathrm{~cm}$ path length cuvettes. Aliquots of $1 \mu \mathrm{l}$ were pipetted onto gridded nitrocellulose membrane and nonspecific binding sites were saturated with $3 \%$ BSA, $0 \cdot 1 \%$ Tween 20 in PBS at room temperature for $1 \mathrm{~h}$. The biotinylated ligand was added to the membrane in $0.1 \%$ Tween 20 in PBS to give a final concentration of $0.3-1.0 \mu \mathrm{g} \mathrm{ml} \mathrm{m}^{-1}$ and incubated at room temperature for $30 \mathrm{~min}$. The membrane was washed three times with PBS, and $0 \cdot 1 \mu \mathrm{g} \mathrm{ml}^{-1}$ streptavidin-HRP was added to the membrane in $0.1 \%$ Tween 20 in PBS and incubated at room temperature for $30 \mathrm{~min}$. The membrane was washed as above and the binding of the ligand was detected by ECL autoradiography. In inhibition experiments, the membrane containing a dilution series of the bacteria (corresponding to $\left.\mathrm{OD}_{600} 4 \cdot 0-0 \cdot 125\right)$ was preincubated with excess ligand at $1 \mathrm{mg}$ $\mathrm{ml}^{-1}$ in $0 \cdot 1 \%$ Tween 20 in PBS for $30 \mathrm{~min}$, the biotinylated ligand was added directly to the preincubation solution and the incubation was continued for $30 \mathrm{~min}$. The binding of the ligand was detected as above. The results shown in Tables 1 , 2 and 3 are given as the reciprocal of the binding titre, defined as the last dilution showing clearly visible binding.

Trypsin treatment and extractions. Bacteria grown and harvested under standard conditions were digested with trypsin at concentrations of $0 \cdot 01-100 \mu \mathrm{g} \mathrm{m}{ }^{-1}$ for $30 \mathrm{~min}$ at $37^{\circ} \mathrm{C}$, after which the digestion was terminated with trypsin inhibitor. In other experiments, the bacteria were suspended in PBS containing $2 \mathrm{M} \mathrm{NaCl}, 1 \%$ Triton X-100 or $10 \mathrm{mM}$ DTT and incubated at room temperature for $1 \mathrm{~h}$, or resuspended in PBS and kept at $80^{\circ} \mathrm{C}$ for $30 \mathrm{~min}$. After the treatments the bacteria were pelleted by centrifugation, washed twice and resuspended in PBS.

Binding of radiolabelled streptococci to thyroglobulin on microtitre plates. Bacteria were grown in $15 \mathrm{ml}$ THY broth containing $0.5 \mathrm{mCi}(18.5 \mathrm{MBq}) \operatorname{Tran}^{35} \mathrm{~S}$-label at $37^{\circ} \mathrm{C}$ overnight. The bacteria were concentrated by centrifugation (3000 $\mathrm{g}$ for $10 \mathrm{~min}$ at $4{ }^{\circ} \mathrm{C}$ ) to $1 \mathrm{ml} \mathrm{PBS}$ and the unbound label was removed by centrifuging the bacteria as above through $5 \mathrm{ml} 6 \%$ BSA in PBS. Microtitre plate wells were coated with $100 \mu \mathrm{l}$ of the ligand at $10 \mu \mathrm{g} \mathrm{ml}^{-1}$ at $37^{\circ} \mathrm{C}$ for $2 \mathrm{~h}$. The wells were rinsed with PBS and saturated with $2 \%$ BSA, $0 \cdot 1 \%$ Tween 20 in PBS for $1 \mathrm{~h}$ at room temperature. The wells were overlaid with $100 \mu \mathrm{l}$ bacteria in $0 \cdot 1 \%$ BSA, $0.05 \%$ Tween 20 in PBS at a concentration that gave an $\mathrm{OD}_{600}$ of $0 \cdot 3$ ( $\sim 4 \times 10^{8}$ c.f.u. $\mathrm{ml}^{-1}$ ), incubated for $1.5 \mathrm{~h}$ at $37^{\circ} \mathrm{C}$ with gentle agitation and washed three times for 10 min with $200 \mu \mathrm{l}$ PBS per well. In inhibition experiments, the bacteria were preincubated with excess ligand at $1 \mathrm{mg} \mathrm{ml}^{-1}$ in $0 \cdot 1 \%$ BSA, 
$0.05 \%$ Tween 20 in PBS for $30 \mathrm{~min}$ and then added to the wells. Binding of the bacteria to wells coated with $2 \%$ BSA was used as control. Experiments were carried out in 12 parallel wells. The bound bacteria were detected using a liquid-scintillation counter.

Conventional DNA techniques. Plasmid DNA preparation from Esc. coli, restriction enzyme digestions, ligations, transformations, agarose gel electrophoresis and Southern blotting were performed as described by Sambrook et al. (1989). Chromosomal S. pyogenes DNA was prepared as described by Caparon \& Scott (1991).

Transposon mutagenesis and analysis of the mutants. Transposon mutagenesis was performed as described by Caparon \& Scott (1991). Briefly, a spontaneous streptomycinresistant $S$. pyogenes strain (A8173sr) was grown overnight in $100 \mathrm{ml}$ THY broth containing $1 \mathrm{mg}$ streptomycin $\mathrm{ml}^{-1}$ at $37^{\circ} \mathrm{C}$. Donor strain Ent. faecalis CG110 (provided by D. Clewell, University of Michigan, Ann Arbor, USA) was grown similarly in $10 \mathrm{ml}$ THY broth containing $10 \mu \mathrm{g}$ tetracycline $\mathrm{ml}^{-1}$. Bacteria were harvested and A8173sr was resuspended in $1 \mathrm{ml} \mathrm{THY}$. Ent. faecalis was resuspended in $10 \mathrm{ml}$ THY. One millilitre of both suspensions were mixed together, plated on THY plates (no antibiotics) and grown overnight at $37^{\circ} \mathrm{C}$. Bacteria were collected from the overnight culture, plated on THY plates containing $1 \mathrm{mg}$ streptomycin $\mathrm{ml}^{-1}$ and $5 \mu \mathrm{g}$ tetracycline $\mathrm{ml}^{-1}$ and grown for $48 \mathrm{~h}$ at $37^{\circ} \mathrm{C}$. Colonies were blotted onto nitrocellulose membranes and were analysed by the glycoprotein-binding assay using diaminobenzidine as substrate. The number of transposons integrated into the genomes of the non-binding mutants was determined by Southern hybridization of HindIII-digested genomic DNAs using $\left[\alpha^{32} \mathrm{P}\right] \mathrm{dCTP}$-labelled plasmid pAM120 (which carries the whole Tn916 transposon; provided by D. Clewell) as the probe.

Cloning of the Tn916-chromosomal DNA junction fragment. Chromosomal DNA from Streptococcus pyogenes mutated with Tn916 was cleaved with HindIII and the fragments were separated by agarose gel electrophoresis. A $14 \mathrm{~kb}$ fragment containing the $5^{\prime}$ end of Tn916 was extracted from the gel, cleaved with HincII and ligated to pBS13 + (Promega) The ligation mixture was transformed into Esc. coli JM109, the bacteria were grown overnight and the colonies transferred to a nylon membrane. The membrane was probed with $[\gamma-$ ${ }^{32} \mathrm{P}$ ]ATP labelled oligonucleotide Tn1 (5'-GAGTGGTTTTGACCTTGATA-3') which binds to the $5^{\prime}$ end of Tn916 at position 53-72. Plasmid DNA from hybridizing colonies was prepared and the DNA sequenced.

DNA sequencing. DNA was sequenced with a Sequenase 2.0 kit according to the instructions of the manufacturer. Primer Tn1 was used in sequencing reactions. The products were analysed by gel electrophoresis and visualized by autoradiography. The sequence data were analysed with DNAstar software.

Generation of an mga-complemented strain. Plasmid pJRS2050 (Andersson et al., 1996; carries $m g a$ and associated regulatory sequences in pLZ12-Spec; provided by J. Scott, Emory University Health Sciences Center, Atlanta, USA) was electroporated into A8173-1 to generate A8173-1(pJRS2050). The electroporation method described by Simon \& Ferretti (1991) was used with one modification: THY medium was used instead of Todd-Hewitt supplemented with horse serum. As a control, the plasmid pLZ12-Spec (an Esc.coli-S. pyogenes shuttle vector) was introduced into A8173-1 to generate A8173-1(pLZ12-Spec).

\section{RESULTS}

\section{Binding of glycoproteins to streptococci}

To characterize the interaction between streptococci and carbohydrates, an assay to study the binding of glycoproteins to streptococci was developed. The assay is based on the binding of biotinylated ligands to bacterial dots on a nitrocellulose membrane and the detection of the bound ligand by streptavidin-HRP and ECL autoradiography. The glycoproteins used in the assay containing a wide selection of $\mathrm{N}$-linked complex, high-mannose and O-linked glycans were bovine thyroglobulin, bovine fetuin and asialofetuin, and bovine submaxillar mucin (Spiro \& Bhoyroo, 1974; Yet et al., 1988; Strous \& Dekker, 1992; Rawitch et al., 1993). Horse myoglobin and bovine erythrocyte carbonic anhydrase were used as controls representing nonglycosylated proteins.

Six $S$. pyogenes strains representing different infection foci and different geographical origins, six streptococcal strains from the Lancefield groups C and G (wound and throat infections) and six strains from group D were analysed for binding to glycoprotein ligands. Thyroglobulin, fetuin and asialofetuin bound to several $S$. pyogenes, group $\mathrm{C}$ and group $\mathrm{G}$ strains, and submaxillary mucin to $S$. pyogenes and group C strains (Fig. 1). No binding of the control non-glycosylated proteins horse myoglobin and carbonic anhydrase to the bacteria was detected.

Inhibition assays were carried out using excess ligand to inhibit the binding of the glycoproteins to a dilution series of $S$. pyogenes A8173 on nitrocellulose membranes (Table 1). As expected, the binding of biotinylated thyroglobulin to A8173 was abolished when excess bovine thyroglobulin was used as inhibitor, and similar inhibition was obtained with human and porcine thyroglobulin (data not shown). However, fetuin, mucin and asialofetuin inhibited the binding of thyroglobulin to half or less. Binding of fetuin to the bacteria was in turn abolished with excess thyroglobulin, and reduced to half or less when incubated with excess fetuin, mucin or asialofetuin. Likewise, binding of mucin was abolished when excess thyroglobulin was used as inhibitor. Fetuin had no effect on the binding of mucin, but asialofetuin and mucin reduced the binding to half or less. Binding of asialofetuin was abolished with excess thyroglobulin, almost abolished with fetuin and asialofetuin and reduced to half with mucin. The crossinhibitions suggest the presence of a common structural component in the glycoproteins recognized by the bacteria. On the other hand, the partial cross-inhibitions suggest the presence of one or more additional binding targets not shared by all of the glycoproteins.

\section{Extractability of the binding activity}

To characterize the properties of the glycoproteinbinding molecule, bacteria were subjected to various treatments, and the binding of thyroglobulin to a 
Thyroglobulin

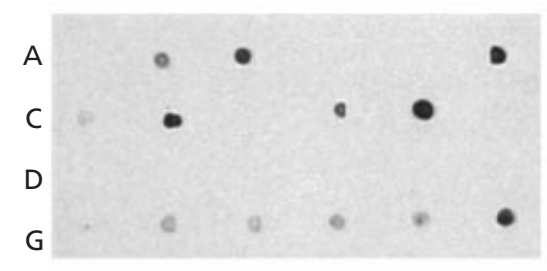

Carbonic anhydrase

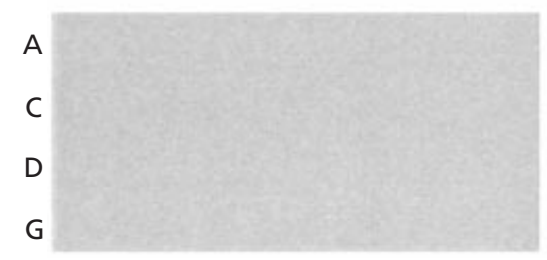

Fetuin

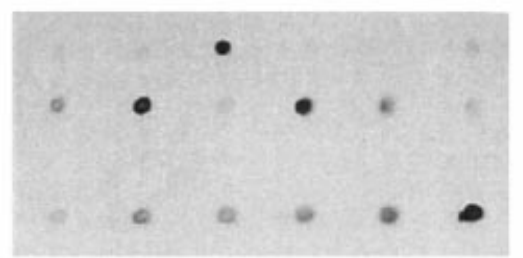

Submaxillary mucin

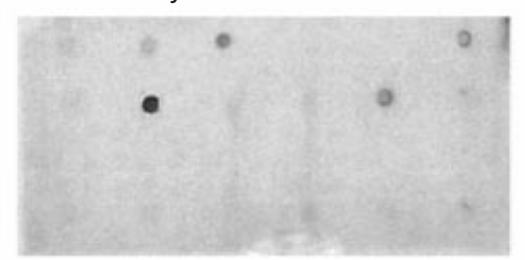

Asialofetuin

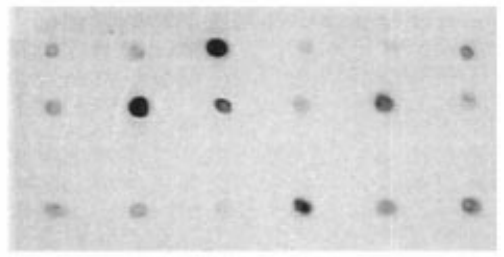

Myoglobin

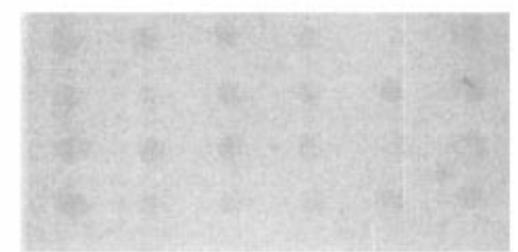

Fig. 1. Binding of glycoproteins to streptococcal strains. Six identical membranes containing six different $S$. pyogenes (A), group $C(C)$, group $D(D)$ and group $G(G)$ strains were prepared by applying $1 \mu$ l aliquots of bacterial suspensions $\left(O_{600}\right.$ $0.5)$ to the membrane. Strain A8173 is in the upper right corner of each membrane. The biotinylated glycoproteins (thyroglobulin, fetuin, asialofetuin, submaxillar mucin) and control non-glycosylated proteins (myoglobin, carbonic anhydrase) were added at concentrations of $0.3-1.0 \mu \mathrm{g} \mathrm{ml}^{-1}$ and the bound ligands were detected after washings with streptavidin-HRP and ECL autoradiography. The films were scanned with a Kodak DC 120 Digital Camera and the data processed with the Kodak Digital Science 1D image analysis system.

Table 1. Cross-inhibition of the binding of glycoproteins to streptococci

Membranes containing dilution series of $S$. pyogenes A8173 were preincubated with $1 \mathrm{mg} \mathrm{ml}^{-1}$ of the inhibitory ligand before addition of the biotinylated binding ligand at $0 \cdot 3 \mu \mathrm{g} \mathrm{ml}^{-1}$ (thyroglobulin) or $1.0 \mu \mathrm{g} \mathrm{ml}^{-1}$ (fetuin, asialofetuin and submaxillary mucin). Results are given as the reciprocal of the binding titre (-, no binding).

\begin{tabular}{|lcccc|}
\hline Inhibitory ligand & \multicolumn{4}{c|}{ Binding ligand } \\
\cline { 2 - 5 } & Thyroglobulin & Fetuin & Asialofetuin & $\begin{array}{c}\text { Submaxilliary } \\
\text { mucin }\end{array}$ \\
\hline None & 32 & 16 & 32 & 16 \\
Thyroglobulin & - & - & - & - \\
Fetuin & 8 & 4 & 1 & 16 \\
Asialofetuin & 16 & 4 & 2 & 4 \\
Submaxillary mucin & 8 & 8 & 16 & 8 \\
\hline
\end{tabular}

dilution series of the bacteria was analysed (Table 2). Trypsin digestion of the bacteria using different enzyme concentrations either reduced or abolished the binding activity, which suggests that the interaction is mediated by a protein on the bacterial surface. Incubation of the bacteria at $80^{\circ} \mathrm{C}$ or in the presence of $2 \mathrm{M} \mathrm{NaCl}, 10 \mathrm{mM}$ DTT or $1 \%$ Triton X-100 had only a minor effect on the thyroglobulin-binding activity, which indicated that the protein is heat stable and tightly attached to the surface of the bacteria.

\section{Adhesion of bacteria to immobilized ligands}

Adhesion of bacteria to thyroglobulin immobilized on microtitre plate wells was investigated to find out whether the glycoprotein-binding activity could support the adhesion of bacteria to glycan-containing surfaces. Metabolically labelled bacteria adhered to the wells coated with thyroglobulin, and the adhesion was inhibited with excess ligand (Fig. 2a). Essentially, no binding was detected to the control BSA-coated surface. These results indicate that $S$. pyogenes can adhere to surfaces coated with thyroglobulin.

\section{Transposon mutagenesis and analysis of the mutants}

Transposon mutagenesis of wild-type strain A8173 was carried out in an attempt to identify the gene that encodes the binding activity. Transposon-harbouring mutants ( $\sim 4000$ colonies) were screened by blotting the mutant colonies onto nitrocellulose membranes and probing them for their binding activity using thyro- 
Table 2. Extractability of the glycoprotein-binding activity

S. pyogenes A8173 bacteria were digested with trypsin at the concentrations indicated for $30 \mathrm{~min}$ at $37^{\circ} \mathrm{C}$, treated with heat, or incubated at room temperature for $1 \mathrm{~h}$ in PBS containing $\mathrm{NaCl}$, Triton X-100 or DTT. The remaining binding activity was assayed with biotinylated thyroglobulin on a dilution series of the bacteria. Binding activity is expressed as the reciprocal of the binding titre (-, no binding).

\begin{tabular}{|lc|}
\hline Treatment & Binding activity \\
\hline Control & 64 \\
Trypsin $\left(\mu \mathrm{g} \mathrm{m}^{-\mathbf{1}}\right)$ & \\
$0 \cdot 01$ & 64 \\
$0 \cdot 1$ & 32 \\
$1 \cdot 0$ & 8 \\
10 & 2 \\
100 & - \\
Heat $\left(80^{\circ} \mathrm{C}, 30 \mathrm{~min}\right)$ & 32 \\
NaCl $(2 \mathrm{M})$ & 32 \\
Triton $\mathrm{X}-100(1 \%)$ & 32 \\
$\mathrm{DTT}(10 \mathrm{mM})$ & 32 \\
\hline
\end{tabular}

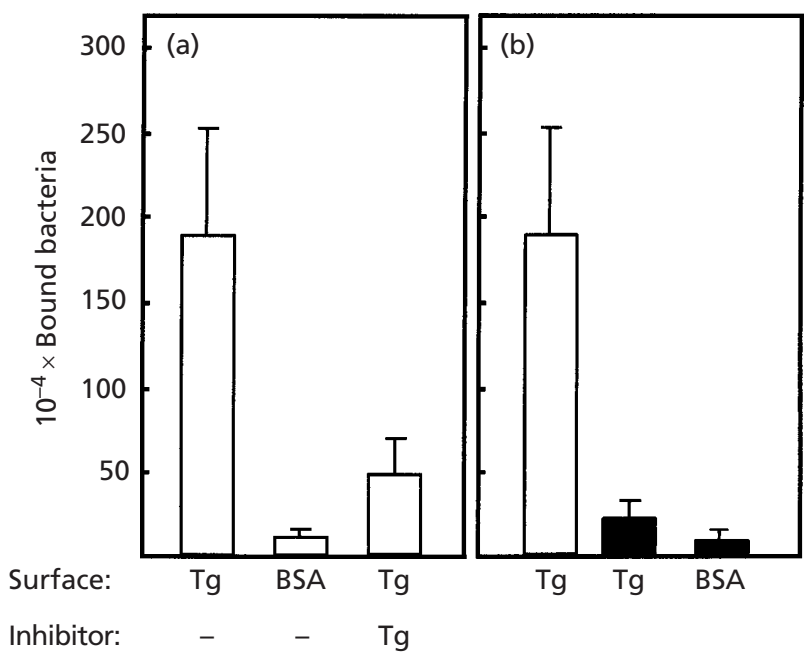

Fig. 2. Binding of radiolabelled streptococci to thyroglobulin on microtitre plates. The wells were coated with $10 \mu \mathrm{g} \mathrm{ml}^{-1}$ thyroglobulin $(\mathrm{Tg})$ and saturated with $2 \%$ BSA, $0.1 \%$ Tween 20 in PBS. Tran ${ }^{35}$ S-labelled bacteria were added and incubated with gentle agitation at $37^{\circ} \mathrm{C}$ for $1.5 \mathrm{~h}$. In the inhibition experiment the bacteria were preincubated with excess thyroglobulin prior to addition to the wells. Binding of the bacteria to wells coated with $2 \%$ BSA was used as control. Results are given as the mean values \pm SD of 12 parallel wells. (a) Binding of S. pyogenes A8173 to thyroglobulin and BSA and the inhibition of binding with excess thyroglobulin. (b) Binding of the mga mutant A8173-1 to thyroglobulin. White bar, A8173; black bars, A8137-1.

globulin as the ligand. Two colonies that did not bind to thyroglobulin (Figs 2b, 3) were identified. The mutant designated A8173-1 was found to harbour one transposon in the genome by Southern hybridization of the

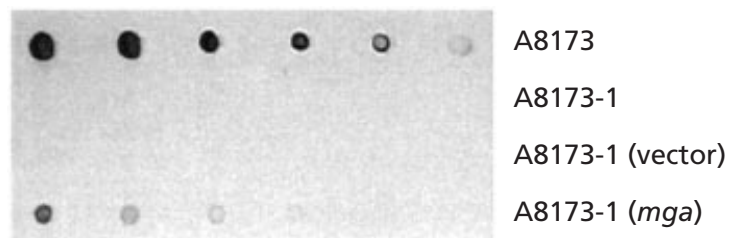

Fig. 3. The glycoprotein-binding activity of wild-type, transposon mutant and mga-complemented bacteria. A membrane containing aliquots of serially diluted $\left(\mathrm{OD}_{600} 4.0\right.$ to 0.125 ) wild-type $S$. pyogenes $A 8173$, the corresponding transposon mutant A8173-1, control strain with vector only and strain complemented with the mga gene was incubated with biotinylated thyroglobulin and the binding was detected as in Fig. 1. Similar results as with thyroglobulin were also obtained with fetuin, asialofetuin and submaxillary mucin.

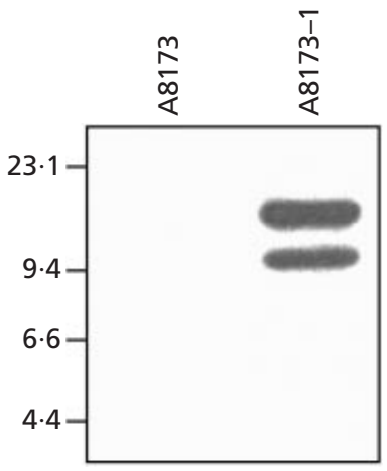

Fig. 4. Determination of the number of the transposons integrated into the genome of A8173-1. Hindlll-digested genomic DNAs of the wild-type A8173 and the corresponding mutant A8173-1 were probed with pAM120 in a Southern hybridization experiment. The two signals arise from the single cleavage site in Tn916. The positions of reference markers (in $\mathrm{kb})$ are indicated.

HindIII-digested genomic DNA with plasmid pAM120 (Fig. 4). A $14 \mathrm{~kb}$ fragment of the A8173-1 genomic DNA that contained the $5^{\prime}$ end of Tn916 was cloned. The DNA was sequenced and the insertion locus was found to be in the $m g a$ gene at position 2076 in the previously published sequence (Podbielski et al., 1995).

\section{Binding activity in an mga-complemented strain and mga regulon mutants}

To confirm that the mutation in the $m g a$ gene was responsible for the loss of $S$. pyogenes A8173 glycoprotein-binding activity, the mutant strain was complemented for mga expression with the plasmid pJRS2050, which carries all of $m g a$ and the regulatory region upstream of $m g a$ in the Esc. coli-S. pyogenes shuttle vector pLZ12-Spec (Andersson et al., 1996). The binding of the glycoproteins to dilution series of the complemented strain A8173-1(pJRS2050) was compared with the binding to the wild-type A8173 and the mutant A8173-1 strains (Fig. 3). Introduction of the $m g a$ gene 
Table 3. Glycoprotein binding activity of mga-regulon mutant strains

\begin{tabular}{|c|c|c|}
\hline Strain* & Characteristics & $\begin{array}{l}\text { Binding } \\
\text { activity } \dagger\end{array}$ \\
\hline M2 71-676 & Wild-type strain, M-type 2 & 64 \\
\hline $\mathrm{M} 2 \mathrm{mga}^{-}$ & Mga- deficient mutant & - \\
\hline $\mathrm{M} 2 \mathrm{emm}^{-}$ & M-protein deficient mutant & 64 \\
\hline $\mathrm{M} 2 \mathrm{fcr}^{-}$ & $\begin{array}{l}\text { IgG-binding-protein deficient } \\
\text { mutant }\end{array}$ & 64 \\
\hline CS101 & Wild-type strain, M-type 49 & 32 \\
\hline $\mathrm{CS}_{101 \mathrm{mga}^{-}}$ & Mga- deficient mutant & - \\
\hline CS101 $\mathrm{mrp}^{-}$ & $\begin{array}{l}\text { IgG-binding-protein deficient } \\
\text { mutant }\end{array}$ & 32 \\
\hline
\end{tabular}

*Described by Podbielski et al. (1996b) and Schmidt et al. (1997).

† Binding activity of biotinylated thyrogobulin on serially diluted bacteria is expressed as the reciprocal of the binding titre $(-$, no binding).
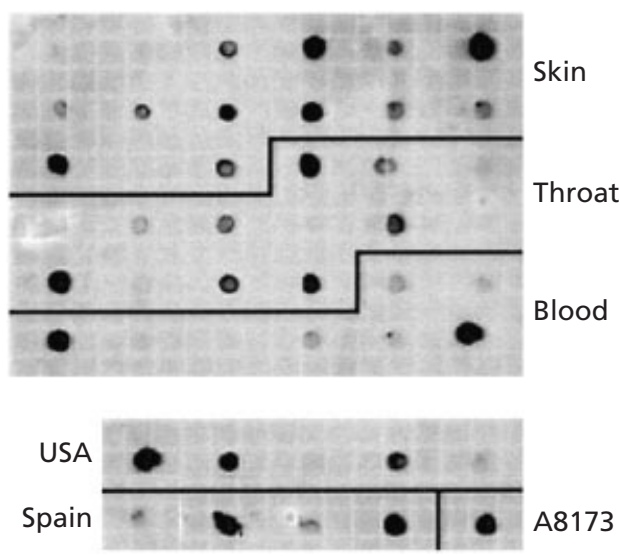

Fig. 5. Prevalence of glycoprotein-binding activity among $S$. pyogenes strains. Bacterial suspensions $\left(\mathrm{OD}_{600} 0.5\right)$ of 46 $S$. pyogenes from various infection foci (throat, skin and blood; Finnish strains) and from other geographical origins (USA, Spain) were pipetted as $1 \mu \mathrm{l}$ aliquots onto nitrocellulose membranes. Binding of thyroglobulin to the bacteria was detected as in Fig. 1 and compared to binding to A8173.

partly restored the thyroglobulin binding activity, while the control plasmid pLZ12-Spec had no effect.

Further evidence for the dependence of the $S$. pyogenes A8173 glycoprotein-binding activity on Mga was obtained by analysing independent, previously characterized mga mutants for their binding to thyroglobulin. As with the A8173 strain, thyroglobulin bound to the M2 71-676 and CS101 wild-type strains. Thyroglobulin showed no binding to the $m g a$ gene insertion mutants of these strains (Table 3). In contrast, binding of thyroglobulin to the emm and fcr mutants of M2 71-676, and to a mrp mutant of CS101 was as strong as to the parental strains, which indicated that neither the M- protein nor the IgG-binding protein, which are regulated by the $m g a$ gene, is responsible for the binding activity.

\section{Prevalence of the binding activity}

Prevalence of the binding activity among S. pyogenes was investigated by studying the binding of thyroglobulin to $46 \mathrm{~S}$. pyogenes strains. The activity was present in at least 32 of the 46 strains studied (Fig. 5). There appeared to be no major difference in the presence of the activity between bacteria from various infection foci (throat, skin and blood), opacity factor positive and negative strains or strains of different $T$ serotypes (not shown), or from different geographical origins (Finland, USA, Spain).

\section{DISCUSSION}

The issue of Streptococcus pyogenes adherence to human epithelial cells is only just beginning to be understood. Some of the S. pyogenes surface components have been identified that mediate the binding of the bacteria to the host epithelial cells, but little is known about the host cell-surface receptors recognized by $S$. pyogenes. The fibronectin-binding adhesin SfbI/ protein F1 has proven to be important in the adherence of the bacteria to host respiratory epithelial cells and to extracellular matrix fibronectin. In addition, these proteins have been demonstrated to promote the invasion of $S$. pyogenes into host cells (Hanski et al., 1992; Talay et al., 1992; Sela et al., 1993; Ozeri et al., 1996, 1998; Molinari et al., 1997; Jadoun et al., 1998). Some studies suggest that M-protein mediates adherence of $S$. pyogenes to epithelial cells and that the receptor structure would be a fucose-containing oligosaccharide of the type found on HEp-2 cells (Tylewska et al., 1988; Wang \& Stinson, 1994a, b). Other studies demonstrate no difference in the binding of an $S$. pyogenes strain and its M-protein defective derivative to human buccal and tonsillar epithelia (Caparon et al., 1991). It has also been proposed that the S. pyogenes hyaluronic acid capsule, which is present on the surface of the most of $S$. pyogenes strains, may serve as a universal mediator of attachment to human keratinocytes of the pharyngeal mucosa and the skin (Schrager $e t$ al., 1998). A hypothetical two-step model where bacterial surface lipoteichoic acid (LTA) has a key role has been proposed for the interaction of streptococci and host cells (Hasty et al., 1992). This model combines the LTA-mediated weak and reversible adherence of the bacteria to the cells with the strong and irreversible binding between fibronectin-binding proteins and fibronectin, or M-protein and an M-protein receptor.

Cell adhesion mechanisms characterized for other streptococci include the interactions between Streptococcus pneumoniae and the oligosaccharide structures Gal $\beta 1-4 G l c N A c \beta 1-3 G a l \beta 1-4 G l c$ (Andersson et al., 1983), GalNAc $\beta 1-4 G a l \beta 1$ - (Krivan et al., 1988), GalNAc $\beta 1$ 3Gal $\alpha 1-4 G a l \beta 1-4 G l c-C e r$ (Cundell \& Tuomanen, 1994) and NeuAc $\alpha 2-3 / 6 \mathrm{Gal} \beta 1$ - (Barthelson et al., 1998) of 
human respiratory epithelial cells. The oligosaccharides were used as inhibitors of binding of pneumococci to epithelial cells. The binding of the meningitis-associated Streptococcus suis to Gal $1-4 \mathrm{Gal}$ and to sialic acidcontaining oligosaccharides are other well characterized interactions of streptococci with oligosaccharide receptors (Liukkonen et al., 1992; Haataja et al., 1993, 1994). Streptococcus sanguis expresses the SSP-5 adhesin, which mediates binding to sialic acid-containing salivary glycoproteins (Demuth et al., 1988, 1990). Anti-adhesion experiments have been carried out in animal models using lacto- $\mathrm{N}$-neo-tetraose and its derivatives to attenuate the course of pneumococcal pneumonia and to prevent colonization of the nasopharynx (Idänpään-Heikkilä et al., 1997; Barthelson et al., 1998).

The results of the present study suggest the presence of a novel glycoprotein-binding activity in S. pyogenes. The presence of the activity is demonstrated both by the binding of soluble glycoproteins to immobilized bacteria, and by the binding of bacteria to immobilized glycoproteins. The activity is different from the $S$. pyogenes fibronectin-binding activity, since the binding of thyroglobulin to A8173 was not inhibited by fibronectin (J. Hytönen \& J. Finne, unpublished results). The glycoprotein-binding activity is present in the majority of $S$. pyogenes strains studied. A similar activity is also found in group C and G streptococci.

There are no major protein sequence similarities between the glycoproteins studied. The cross-inhibitions of the glycoproteins and the absence of binding to nonglycosylated proteins therefore suggest that the receptor structure may be a carbohydrate. On the other hand, the observation that the binding of thyroglobulin is only partially inhibited by fetuin, asialofetuin and mucin may suggest the presence of one or more additional binding activities. Bovine thyroglobulin contains only $\mathrm{N}$-linked glycans (Rawitch et al., 1993) and bovine submaxillary mucin mainly O-linked glycans (Strous \& Dekker, 1992). Fetuin is glycosylated with both $\mathrm{N}$ - and O-linked sialic acid-containing oligosaccharides (Spiro \& Bhoyroo, 1974; Yet et al., 1988). Preliminary experiments using a selection of mono-, di- and trisaccharides as inhibitors of binding did not reveal the binding specificity of the adhesin (P. Isomäki \& J. Finne, unpublished results). The receptor structure could therefore be a more complex or extended structure included in the $\mathrm{N}$ - and/or O-glycans of these glycoproteins, or a structure not apparent in gross peptide sequence comparison analysis.

As indicated by the resistance of the binding protein to solubilizations by salt, detergent, reducing agent and heat treatment, it appears to be tightly anchored to the bacterial surface. Only trypsin digestion removed the activity from the bacteria. These physical characteristics parallel those described for some other streptococcal surface proteins like streptococcal surface dehydrogenase, which was shown to be resistant to $2 \%$ SDS and $2 \mathrm{M} \mathrm{NaCl}$ treatments but sensitive to trypsin digestion (Pancholi \& Fischetti, 1992). Unfortunately, analysis of the trypsin extract of streptococci revealed that the activity was rapidly inactivated and the molecule was therefore not amenable to further purification.

In transposon-mutagenesis experiments, the adhesioninactivating insertion was found to be in the mga gene. The finding that the $S$. pyogenes binding-activity expression is controlled by the $m g a$ gene was confirmed by studying the adhesion of the glycoproteins to independent mga mutant strains, and by complementation with a wild-type $m g a$ gene. That the complementation was partial may be related to the fact that the mga gene used originated from another strain of S. pyogenes. On the other hand, there was binding of the glycoproteins to mutant strains deficient in M-protein and IgG-binding protein, which indicates that these proteins do not mediate the binding activity. The fact that the $m g a$ gene is a regulator of important $S$. pyogenes virulence factors, together with the high prevalence of the glycoproteinbinding activity among S. pyogenes and group C and G strains, suggests that it may have a role in the pathogenicity of streptococci. Further studies including the cloning of the gene are needed in order to characterize the molecular properties of this 'strepadhesin' activity, its receptor specificity and its role in streptococcal virulence.

\section{ACKNOWLEDGEMENTS}

This work was supported by grants from the Sigrid Jusélius Foundation and the Academy of Finland. We thank Drs Michael Boyle, Don Clewell, Pentti Huovinen, Kyllikki Kunnas, Andreas Podbielski and June Scott for kindly providing the bacterial strains and the plasmids, Dr Pasi Niemelä for helpful discussions and Terttu Jompero for technical assistance.

\section{REFERENCES}

Andersson, B., Dahmen, J., Frejd, T., Leffler, H., Magnusson, G., Noori, G. \& Eden, C. S. (1983). Identification of an active disaccharide unit of a glycoconjugate receptor for pneumococci attaching to human pharyngeal epithelial cells. J Exp Med 158, 559-570.

Andersson, G., Mclver, K., Heden, L. O. \& Scott, J. R. (1996). Complementation of divergent $m g a$ genes in group A Streptococcus. Gene $175,77-81$.

Barthelson, R., Mobasseri, A., Zopf, D. \& Simon, P. (1998). Adherence of Streptococcus pneumoniae to respiratory epithelial cells is inhibited by sialylated oligosaccharides. Infect Immun 66, 1439-1444.

Beachey, E. H. (1981). Bacterial adherence: adhesin-receptor interactions mediating the attachment of bacteria to mucosal surface. J Infect Dis 143, 325-345.

Beuth, J., Stoffel, B. \& Pulverer, G. (1996). Inhibition of bacterial adhesion and infections by lectin blocking. Adv Exp Med Biol 408, 51-56.

Caparon, M. G. \& Scott, J. R. (1991). Genetic manipulation of pathogenic streptococci. Methods Enzymol 204, 556-586.

Caparon, M. G., Stephens, D. S., Olsen, A. \& Scott, J. R. (1991). Role of $\mathrm{M}$ protein in adherence of group A streptococci. Infect Immun 59, 1811-1817.

Chelsom, J., Halstensen, A., Haga, T. \& Hoiby, E. A. (1994). 
Necrotising fasciitis due to group A streptococci in western Norway: incidence and clinical features. Lancet 344, 1111-1115.

Chen, C. C. \& Cleary, P. P. (1990). Complete nucleotide sequence of the streptococcal C5a peptidase gene of Streptococcus pyogenes. J Biol Chem 265, 3161-3167.

Cleary, P. \& Retnoningrum, D. (1994). Group A streptococcal immunoglobulin-binding proteins: adhesins, molecular mimicry or sensory proteins? Trends Microbiol 2, 131-136.

Courtney, H. S., Hasty, D. L., Dale, J. B. \& Poirier, T. P. (1992). A 28-kilodalton fibronectin-binding protein of group A streptococci. Curr Microbiol 25, 245-250.

Courtney, H. S., Li, Y., Dale, J. B. \& Hasty, D. L. (1994). Cloning, sequencing, and expression of a fibronectin/fibrinogen-binding protein from group A streptococci. Infect Immun 62, 3937-3946.

Cundell, D. R. \& Tuomanen, E. I. (1994). Receptor specificity of adherence of Streptococcus pneumoniae to human type-II pneumocytes and vascular endothelial cells in vitro. Microb Pathog 17, 361-374.

Demuth, D. R., Davis, C. A., Corner, A. M., Lamont, R. J., Leboy, P. S. \& Malamud, D. (1988). Cloning and expression of a Streptococcus sanguis surface antigen that interacts with a human salivary agglutinin. Infect Immun 56, 2484-2490.

Demuth, D. R., Golub, E. E. \& Malamud, D. (1990). Streptococcalhost interactions: structural and functional analysis of a Streptococcus sanguis receptor for a human salivary glycoprotein. J Biol Chem 265, 7120-7126.

Fischetti, V. A., Jones, K. F., Hollingshead, S. K. \& Scott, J. R. (1988). Structure, function, and genetics of streptococcal $M$ protein. Rev Infect Dis 10 Suppl 2, 356-359.

Gubbe, K., Misselwitz, R., Welfle, K., Reichardt, W., Schmidt, K. H. \& Welfle, H. (1997). C repeats of the streptococcal M1 protein achieve the human serum albumin binding ability by flanking regions which stabilize the coiled-coil conformation. Biochemistry 36, 8107-8113.

Haataja, S., Tikkanen, K., Liukkonen, J., François-Gerard, C. \& Finne, J. (1993). Characterization of a novel bacterial adhesion specificity of Streptococcus suis recognizing blood group $\mathrm{P}$ receptor oligosaccharides. J Biol Chem 268, 4311-4317.

Haataja, S., Tikkanen, K., Nilsson, U., Magnusson, G., Karlsson, K. A. \& Finne, J. (1994). Oligosaccharide-receptor interaction of the Gal $\alpha 1-4 \mathrm{Gal}$ binding adhesin of Streptococcus suis : combining site architecture and characterization of two variant adhesin specificities. J Biol Chem 269, 27466-27472.

Hanski, E. \& Caparon, M. (1992). Protein F, a fibronectin-binding protein, is an adhesin of the group A streptococcus Streptococcus pyogenes. Proc Natl Acad Sci USA 89, 6172-6176.

Hanski, E., Horwitz, P. A. \& Caparon, M. G. (1992). Expression of protein F, the fibronectin-binding protein of Streptococcus pyogenes JRS4, in heterologous streptococcal and enterococcal strains promotes their adherence to respiratory epithelial cells. Infect Immun 60, 5119-5125.

Hasty, D. L., Ofek, I., Courtney, H. S. \& Doyle, R. J. (1992). Multiple adhesins of streptococci. Infect Immun 60, 2147-2152.

Idänpään-Heikkilä, I., Simon, P. M., Zopf, D., Vullo, T., Cahill, P., Sokol, K. \& Tuomanen, E. (1997). Oligosaccharides interfere with the establishment and progression of experimental pneumococcal pneumonia. J Infect Dis 176, 704-712.

Jadoun, J., Ozeri, V., Burstein, E., Skutelsky, E., Hanski, E. \& Sela, S. (1998). Protein F1 is required for efficient entry of Streptococcus pyogenes into epithelial cells. J Infect Dis 178, 147-158.

Jaffe, J., Natanson-Yaron, S., Caparon, M. G. \& Hanski, E. (1996). Protein F2, a novel fibronectin-binding protein from Strepto- coccus pyogenes, possesses two binding domains. Mol Microbiol 21, 373-384.

Karlsson, K. A. (1995). Microbial recognition of target-cell glycoconjugates. Curr Opin Struct Biol 5, 622-635.

Kataja, J., Huovinen, P., Muotiala, A., Vuopio-Varkila, J., Efstratiou, A., Hallas, G. \& Seppälä, H. (1998a). Clonal spread of group A streptococcus with the new type of erythromycin resistance: Finnish study group for antimicrobial resistance. $J$ Infect Dis 177, 786-789.

Kataja, J., Seppälä, H., Skurnik, M., Sarkkinen, H. \& Huovinen, P. (1998b). Different erythromycin resistance mechanisms in group C and group G streptococci. Antimicrob Agents Chemother 42, 1493-1494.

Kreikemeyer, B., Talay, S. R. \& Chhatwal, G. S. (1995). Characterization of a novel fibronectin-binding surface protein in group A streptococci. Mol Microbiol 17, 137-145.

Krivan, H. C., Roberts, D. D. \& Ginsburg, V. (1988). Many pulmonary pathogenic bacteria bind specifically to the carbohydrate sequence GalNAc $\beta 1-4 \mathrm{Gal}$ found in some glycolipids. Proc Natl Acad Sci USA 85, 6157-6161.

Liukkonen, J., Haataja, S., Tikkanen, K., Kelm, S. \& Finne, J. (1992). Identification of $N$-acetylneuraminyl $\alpha 2 \rightarrow 3$ poly- $N$-acetyllactosamine glycans as the receptors of sialic acid-binding Streptococcus suis strains. J Biol Chem 267, 21105-21111.

Molinari, G., Talay, S. R., Valentin-Weigand, P., Rohde, M. \& Chhatwal, G. S. (1997). The fibronectin-binding protein of Streptococcus pyogenes, $\mathrm{SfbI}$, is involved in the internalization of group A streptococci by epithelial cells. Infect Immun 65, 1357-1363.

Mouricout, M., Petit, J. M., Carias, J. R. \& Julien, R. (1990). Glycoprotein glycans that inhibit adhesion of Escherichia coli mediated by K99 fimbriae: treatment of experimental colibacillosis. Infect Immun 58, 98-106.

Ofek, I. \& Sharon, N. (1990). Adhesins as lectins: specificity and role in infection. Curr Top Microbiol Immunol 151, 91-114.

Ozeri, V., Tovi, A., Burstein, I., Natanson-Yaron, S., Caparon, M. G., Yamada, K. M., Akiyama, S. K., Vlodavsky, I. \& Hanski, E. (1996). A two-domain mechanism for group A streptococcal adherence through protein $\mathrm{F}$ to the extracellular matrix. EMBO J 15, 989-998.

Ozeri, V., Rosenshine, I., Mosher, D. F., Fassler, R. \& Hanski, E. (1998). Roles of integrins and fibronectin in the entry of Streptococcus pyogenes into cells via protein F1. Mol Microbiol 30, 625-637.

Pancholi, V. \& Fischetti, V. A. (1992). A major surface protein on group A streptococci is a glyceraldehyde-3-phosphate dehydrogenase with multiple binding activity. J Exp Med 176, 415-426.

Podbielski, A., Flosdorff, A. \& Weber-Heynemann, J. (1995). The group A streptococcal virR49 gene controls expression of four structural vir regulon genes. Infect Immun 63, 9-20.

Podbielski, A., Woischnik, M., Pohl, B. \& Schmidt, K. H. (1996a). What is the size of the group A streptococcal vir regulon? The Mga regulator affects expression of secreted and surface virulence factors. Med Microbiol Immunol Berl 185, 171-181.

Podbielski, A., Schnitzler, N., Beyhs, P. \& Boyle, M. D. P. (1996b). M-related protein (Mrp) contributes to group A streptococcal resistance to phagocytosis by human granulocytes. Mol Microbiol 19, 429-441.

Rakonjac, J. V., Robbins, J. C. \& Fischetti, V. A. (1995). DNA sequence of the serum opacity factor of group A streptococci: identification of a fibronectin-binding repeat domain. Infect Immun 63, 622-631.

Rawitch, A. B., Pollock, H. G. \& Yang, S. X. (1993). Thyroglobulin 
glycosylation: location and nature of the $\mathrm{N}$-linked oligosaccharide units in bovine thyroglobulin. Arch Biochem Biophys 300, 271-279.

Rocha, C. L. \& Fischetti, V. A. (1999). Identification and characterization of a novel fibronectin-binding protein on the surface of group A streptococci. Infect Immun 67, 2720-2728.

Sambrook, J., Fritsch, E. F. \& Maniatis, T. (1989). Molecular Cloning: a Laboratory Manual, 2nd edn. Cold Spring Harbor, NY: Cold Spring Harbor Laboratory.

Schmidt, K. H., Mann, K., Cooney, J. \& Kohler, W. (1993). Multiple binding of type 3 streptococcal $\mathrm{M}$ protein to human fibrinogen, albumin and fibronectin. FEMS Immunol Med Microbiol 7, 135-143.

Schmidt, K. H., Podbielski, A., Raeder, R. \& Boyle, M. D. P. (1997). Inactivation of single genes within the virulence regulon of an M2 group A streptococcal isolate results in differences in virulence for chicken embryos and for mice. Microb Pathog 23, 347-355.

Schrager, H. M., Alberti, S., Cywes, C., Dougherty, G. J. \& Wessels, M. R. (1998). Hyaluronic acid capsule modulates M proteinmediated adherence and acts as a ligand for attachment of group A streptococcus to CD44 on human keratinocytes. J Clin Invest 101, 1708-1716.

Sela, S., Aviv, A., Tovi, A., Burstein, I., Caparon, M. G. \& Hanski, E. (1993). Protein F: an adhesin of Streptococcus pyogenes binds fibronectin via two distinct domains. Mol Microbiol 10, 1049-1055.

Sharon, N. (1996). Carbohydrate-lectin interactions in infectious disease. Adv Exp Med Biol 408, 1-8.

Sharon, N. \& Lis, H. (1997). Microbial lectins and their glycoprotein receptors. In Glycoproteins II, pp. 475-506. Edited by J. Montreuil, J. F. G. Vliegenthart \& H. Schachter. Amsterdam: Elsevier.

Simon, D. \& Ferretti, J. J. (1991). Electrotransformation of Streptococcus pyogenes with plasmid and linear DNA. FEMS Microbiol Lett 66, 219-224.
Spiro, R. G. \& Bhoyroo, V. D. (1974). Structure of the Oglycosidically linked carbohydrate units of fetuin. J Biol Chem 249, 5704-5717.

Strous, G. J. \& Dekker, J. (1992). Mucin-type glycoproteins. Crit Rev Biochem Mol Biol 27, 57-92.

Talay, S. R., Ehrenfeld, E., Chhatwal, G. S. \& Timmis, K. N. (1991). Expression of the fibronectin-binding components of Streptococcus pyogenes in Escherichia coli demonstrates that they are proteins. Mol Microbiol 5, 1727-1734.

Talay, S. R., Valentin-Weigand, P., Jerlstrom, P. G., Timmis, K. N. \& Chhatwal, G. S. (1992). Fibronectin-binding protein of Streptococcus pyogenes: sequence of the binding domain involved in adherence of streptococci to epithelial cells. Infect Immun 60, 3837-3844.

Tylewska, S. K., Fischetti, V. A. \& Gibbons, R. J. (1988). Binding selectivity of Streptococcus pyogenes and M-protein to epithelial cells differs from that of lipoteichoic acid. Curr Microbiol 16, 209-216.

Wang, J. R. \& Stinson, M. W. (1994a). M protein mediates streptococcal adhesion to HEp-2 cells. Infect Immun 62, 442-448.

Wang, J. R. \& Stinson, M. W. (1994b). Streptococcal M6 protein binds to fucose-containing glycoproteins on cultured human epithelial cells. Infect Immun 62, 1268-1274.

Yet, M. G., Chin, C. C. \& Wold, F. (1988). The covalent structure of individual $\mathrm{N}$-linked glycopeptides from ovomucoid and asialofetuin. J Biol Chem 263, 111-117.

Zopf, D. \& Roth, S. (1996). Oligosaccharide anti-infective agents. Lancet 347, 1017-1021.

Zopf, D., Simon, P., Barthelson, R., Cundell, D., Idänpään-Heikkilä, I. \& Tuomanen, E. (1996). Development of anti-adhesion carbohydrate drugs for clinical use. Adv Exp Med Biol 408, 35-38.

Received 6 September 1999; accepted 22 September 1999. 